\title{
APLICAÇÃO DA TÉCNICA DO DNA BARCODING NA IDENTIFICAÇÃO DE ESPÉCIES DE MORCEGOS ATROPELADOS NA BR 101 NA RESERVA BIOLÓGICA DE SOORETAMA-ES
}

\author{
Laís Amorim ${ }^{1}$ \\ Natan Silva matos ${ }^{2}$ \\ Lucas Damásio ${ }^{3}$ \\ Aureo Banhos ${ }^{4}$ \\ Greiciane G. Paneto ${ }^{5}$
}

Resumo: O DNA barcoding (código de barras de DNA) é uma técnica muito utilizada em estudos genéticos com animais que utiliza iniciadores universais para amplificar uma região específica do DNA mitocondrial. Esta técnica propicia a identificação de espécies que são encontradas muito danificadas, cuja identificação morfológica é praticamente impossível, principalmente de espécies de pequeno porte. O presente trabalho utilizou o DNA barcoding para a identificação de 33 amostras de espécies de morcegos atropeladas na Reserva Biológica de Sooretama-ES, uma região que tem um grande impacto, devido aos atropelamento causado pelo constante tráfego de carros que passam pela BR 101 que corta transversalmente a mesma. Para a identificação dos animais foi feita uma extração do DNA das amostras, e a subunidade I do gene COI do DNA mitocondrial foi amplificado por PCR, sendo em seguida sequenciado. Posteriormente, as amostras identificadas foram confrontadas no banco de dados BOLD. Foram selecionadas 33 amostras de DNA, e 27 dessas renderam sequenciamento adequado que permitiram a identificação dos animais, após o confronto das sequências de nucleotídeos geradas com o banco de dados BOLD. Deste modo, 17 espécies de morcegos foram identificadas.

Palavras-chave: DNA barcoding; Morcegos; Sooretama; Espécies.

\footnotetext{
1 Ciências Biológicas/Universidade Federal do Espírito Santo/Departamento de Biologia, Brasil. E-mail: laisguvi@hotmail.com.

2 Farmácia/ Universidade Federal do Espírito Santo, Brasil/Departamento de Farmácia e Nutrição, Brasil. E-mail: natan.matos@hotmail.com.

3 Ciências Biológicas/Universidade Federal do Espírito Santo/Departamento de Biologia, Brasil. E-mail: damasioler@gmail.com.

${ }^{4}$ Universidade Federal do Espírito Santo/Departamento de Biologia, Brasil. E-mail: aureobs@gmail.com.

5 Farmácia/Universidade Federal do Espírito Santo/Departamento de Farmácia e Nutrição, Brasil. E-mail: ggpaneto@gmail.com.
} 